\title{
Corrigendum: How ready are our health systems to implement prevention of mother to child transmission Option B+?
}

\author{
Authors: \\ Palesa Nkomo ${ }^{1}$ \\ Natasha Davies ${ }^{2}$ \\ Gayle Sherman ${ }^{3,4}$ \\ Sanjana Bhardwaj ${ }^{5}$ \\ Vundli Ramokolo ${ }^{1}$ \\ Nobubelo K. Ngandu ${ }^{1}$ \\ Nobuntu Noveve \\ Trisha Ramraj ${ }^{1}$ \\ Vuyolwethu Magasana ${ }^{1}$ \\ Yages Singh ${ }^{1}$ \\ Duduzile Nsibande ${ }^{1}$ \\ Ameena E. Goga ${ }^{1,6}$

\section{Affiliations:} \\ ${ }^{1}$ Health Systems Research \\ Unit, South African Medical \\ Research Council, \\ South Africa \\ ${ }^{2}$ Wits Reproductive Health \\ and HIV Institute, University \\ of the Witwatersrand, \\ South Africa \\ ${ }^{3}$ National Institute for \\ Communicable Diseases, \\ Johannesburg, South Africa \\ ${ }^{4}$ Department of Paediatrics \\ and Child Health, University \\ of the Witwatersrand, \\ South Africa \\ ${ }^{5}$ The United Nations \\ Children's Fund, Pretoria, \\ South Africa \\ ${ }^{6}$ Department of Paediatrics, \\ University of Pretoria, \\ South Africa \\ Correspondence to: \\ Palesa Nkomo \\ Email: \\ palesa.nkomo@mrc.ac.za \\ Postal address: \\ Private Bag X385, Pretoria \\ 0002, South Africa

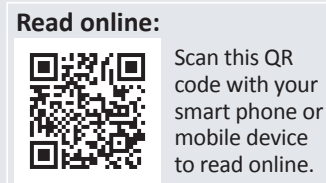

The authors apologise for two oversights in Box 1: One was due to non-deletion of a bullet point; the other was an omission.

The June update of the new January 2015 South African (SA) PMTCT guideline states that infants should no longer be tested for HIV infection at 6 weeks.

Box 1 illustrates the PCR infant HIV testing time points. Six weeks testing has been removed from the revised Box (please see below).

Additionally, information about HIV infant test confirmation was omitted. This information has now been added as the last row in the revised Box (please see below). According to the new January 2015 SA PMTCT guideline a second infant HIV PCR test is used to confirm infant HIV infection following a first positive HIV PCR test. The new January 2015 SA PMTCT guideline no longer recommends infant viral load as a confirmatory test.
Dates: Published: 26 Nov. 2015

How to cite this article: Nkomo P, Davies N, Sherman G, et al. Corrigendum: How ready are our health systems to implement prevention of mother to child transmission Option B+? S Afr J HIV Med. 2015;16(1), Art. \#386, 2 pages. http://dx.doi.org/10.4102/sajhivmed. v16i1.386-1

Note: Doi of original article: http://dx.doi.org/10.4102/sajhivmed.v16i1.386

Copyright: @ 2015. The Authors. Licensee: AOSIS OpenJournals. This work is licensed under the Creative Commons Attribution License. 
Please see below the revised Box.

BOX 1: Key changes between the 2013 and January 2015 South Africa prevention of mother to child transmission guidelines.

\begin{tabular}{|c|c|}
\hline 2013 South African PMTCT guideline & New January 2015 South African PMTCT guideline \\
\hline No mention of HIV testing amongst children. & $\begin{array}{l}\text { Children aged } \geq 12 \text { years may self-consent to an HIV test if they are of sufficient maturity to } \\
\text { understand the benefits, risk and social implications. }\end{array}$ \\
\hline $\begin{array}{l}\text { Re-testing of HIV-negative mothers or mothers of unknown HIV status: } \\
\text { should be tested for HIV at } 6 \text { weeks, } 3 \text { months, } 9 \text { months and } 1 \text { year postpartum, } \\
\text { particularly if they are breast feeding. }\end{array}$ & $\begin{array}{l}\text { Re-testing of HIV-negative mothers: } \\
\text { - 3-monthly through pregnancy } \\
\text { - at labour/delivery } \\
\text { testing) } \\
\text { - } 12 \text {-weekly throughout breastfeeding till } 24 \text { months if breastfeeding continued. }\end{array}$ \\
\hline $\begin{array}{l}\text { CD4 cell count } \leq 350 \text { cells } / \mu \mathrm{L} \text { used to guide eligibility for ART: amongst pregnant } \\
\text { women without stage } 3 / 4 \text { disease or amongst non-pregnant HIV-positive patients } \\
\text { with stage } 3 / 4 \text { disease. } \\
\text { CD4 cell count used for monitoring of ART at } 12 \text { months post initiation. }\end{array}$ & 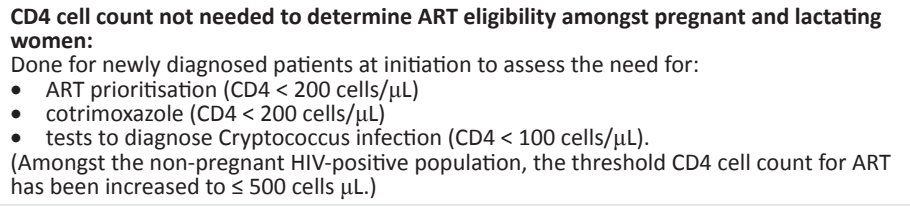 \\
\hline $\begin{array}{l}\text { Initiate lifelong ART: } \\
\text { - in all pregnant women with CD4 cell count } \leq 350 \text { or stage } 3 / 4 \text { disease } \\
\text { - all HIV-positive children }<5 \text { years old }- \text { immediately for infants and within } \\
2 \text { weeks for children between } 1 \text { and } 5 \text { years } \\
\text { TB/HIV co-infected pregnant women. } \\
\text { Initiate 'feeding-dependent' ART until } 1 \text { week after complete cessation of } \\
\text { breastfeeding in women with CD4 }>350 \text { without stage } 3 / 4 \text { disease. }\end{array}$ & $\begin{array}{l}\text { Initiate lifelong ART regardless of CD4 cell count for: } \\
\text { - HIV-positive pregnant, breastfeeding women, or women within } 1 \text { year post partum for } \\
\text { life } \\
\text { - HIV-positive women who attend for choice of termination of pregnancy (CTOP) } \\
\text { (included in the } 2015 \text { PMTCT training package) } \\
\text { - HIV-positive children }<5 \text { years (discussed in more detail in the paediatric guidelines) } \\
\text { HIV/TB or HIV/hepatitis B co-infected women. } \\
\text { Duration of ART not dependent on feeding practice. }\end{array}$ \\
\hline Efavirenz (EFV) not used in first trimester of pregnancy amongst women on ART. & Efavirenz (EFV) used in first trimester of pregnancy amongst women on ART. \\
\hline $\begin{array}{l}\text { Viral load monitoring at first ANC if ART initiated before pregnancy and at } 6 \text { and } \\
12 \text { months post initiation. }\end{array}$ & $\begin{array}{l}\text { Viral load monitoring at first ANC if ART initiated before pregnancy or within } 3 \text { months } \\
\text { if ART initiated antenatally or during breastfeeding. Thereafter } 6 \text {-monthly viral load } \\
\text { monitoring. }\end{array}$ \\
\hline Daily infant nevirapine for 6 weeks from as soon as possible post delivery. & $\begin{array}{l}\text { As for } 2013 \text { plus infant nevirapine could continue for } 12 \text { weeks if maternal ART adherence } \\
\text { has been suboptimal or maternal viral load }>1000 \text { copies/ } \mu \text { L or mother is newly diagnosed } \\
\text { during breastfeeding. } \\
\text { For newly diagnosed HIV-positive breastfeeding mothers, infant AZT and nevirapine should } \\
\text { be initiated immediately. If infant PCR is negative, infant AZT can stop; but infant nevirapine } \\
\text { should continue for } 12 \text { weeks. } \\
\text { In HIV exposed infants }<18 \text { months, infant nevirapine prophylaxis can be initiated if infant } \\
\text { HIV rapid test result is not available or is positive, whilst awaiting infant's PCR result. }\end{array}$ \\
\hline $\begin{array}{l}\text { Infant PCR testing to be conducted at: } \\
\text { birth in symptomatic infants failing to thrive (includes low birth weight, } \\
\text { haematological abnormality such as anaemia or thrombocytopaenia, } \\
\text { congenital pneumonia, hepatosplenomegaly, extensive oral candidiasis, } \\
\text { significant lymphadenopathy, any opportunistic infections) } \\
6 \text { weeks in all HIV-exposed infants } \\
6 \text { weeks post cessation of breastfeeding if aged }<18 \text { months and rapid HIV } \\
\text { test if aged } \geq 18 \text { months } \\
\text { rapid HIV testing at } 18 \text { months. } \\
\text { Abandoned infants should receive NVP }<72 \text { hours post delivery and continued } \\
\text { until HIV-exposure status has been determined. If the HIV rapid/ELISA test is } \\
\text { positive, continue nevirapine until } 6 \text { weeks of age and do a PCR at } 6 \text { weeks. If the } \\
\text { HIV rapid test result cannot be determined within } 2 \text { hours of encountering an } \\
\text { abandoned baby, a stat dose of NVP is warranted. }\end{array}$ & $\begin{array}{l}\text { Infant PCR testing to be conducted at: } \\
\text { birth, or as soon as possible after birth amongst all HIV exposed infants } \\
\text { - } 10 \text { weeks in infants not testing HIV positive at birth } \\
16 \text { weeks in infants receiving } 12 \text { weeks nevirapine } \\
\text { - } 6 \text { weeks post cessation of breastfeeding if aged < } 18 \text { months and rapid HIV tests if aged } \\
\geq 18 \text { months } \\
\text { - rapid HIV testing at } 18 \text { months for all HIV-exposed infants, for infants born to mothers } \\
\text { of unknown HIV status, and for infants breastfed by a woman of unknown HIV status. } \\
\text { For infants }<18 \text { months, HIV rapid testing can be conducted to determine infant HIV- } \\
\text { exposure. } \\
\text { Abandoned infants - protocol as for } 2013 \text { guidelines. }\end{array}$ \\
\hline $\begin{array}{l}\text { Infant viral load: } \\
\text { - used to confirm infant HIV infection following a first positive HIV PCR test }\end{array}$ & $\begin{array}{l}\text { Second infant HIV PCR test: } \\
\text { - used to confirm infant HIV infection following the first positive HIV PCR test, infant viral } \\
\text { load not used. }\end{array}$ \\
\hline
\end{tabular}

